\title{
PENERAPAN METODE LAWARAN UNTUK MENINGKATKAN KETERAMPILAN DAN MOTIVASI MEMBACA HURUF JAWA PADA PESERTA DIDIK KELAS 3 SD 2 HONGGOSOCO KECAMATAN JEKULO KABUPATEN KUDUS TAHUN PELAJARAN 2014/2015
}

\author{
Sri Hastutik \\ SD 2 Honggosoco \\ email: srihastutikspd61@gmail.com
}

\begin{abstract}
The goal is to improve: 1) reading skills Javanese script, using lawaran; and 2) the motivation of learners in the learning, that liveliness, interest, desire of students to learn to read in accordance with the technique Javanese Javanese read correctly. This research is a classroom action research (CAR) conducted in SD 2 Honggosoco Jekulo District of Kudus, with the subject of grade 3 learners first semester of academic year 2014/2015. Number of students there are 21, with details of nine men and 12 women. As for who becomes the object of research is learning to read Javanese. The research process was conducted in two cycles which include four stages, namely the planning phase, the implementation phase, the stage of observation, as well as the stage of analysis and reflection. Based on the results of the research, there is an increase in the quality of learning both the process and the results read Javanese learners 3rd grade 2 Honggosoco Jekulo District of Kudus. Improving the quality of the learning process is characterized by increasing: 1) the number of quality students who are active in apersepsi activities and in learning activities; 2) the number of learners who are interested and motivated in learning reading Javanese script; and 3) the number of learners who are able to read Java script with the correct technique using lawaran. As for improving the quality of learning outcomes characterized by an increasing number of students who reach the limit of completeness, that in cycle 1 was 15 learners from 22 students $(71 \%)$, which reached category fairly and well. In cycle 2 to 22 students (100\%). While the average speed reading reached 25.96. As effective measures undertaken by the researchers to optimize these methods, among others: 1) divides the learners in groups based differences in literacy levels in Javanese script; 2) provide opportunities for learners to practice reading through a Java script lawaran method; 3) integrate Java script reading skills with language skills, such as speaking, writing, and listening; and 4) applying read Java script in art activities in the school environment is particularly suitable learners experience gained during the study. Fundamental principle of this method is to know, to practice, apply, demonstrate, so that learners actualize Javanese read correctly.
\end{abstract}

Keywords: Reading Javanese, Lawaran.

\begin{abstract}
ABSTRAK
Tujuan yang hendak dicapai adalah untuk meningkatkan : 1) keterampilan membaca aksara Jawa, dengan menggunakan metode lawaran; dan 2) motivasi peserta didik dalam pembelajaran, yaitu keaktifan, ketertarikan, keinginan peserta didik untuk belajar membaca aksara Jawa sesuai dengan teknik membaca aksara Jawa dengan benar.
\end{abstract}


Penelitian ini merupakan penelitian tindakan kelas (PTK) yang dilakukan di SD 2 Honggosoco Kecamatan Jekulo Kabupaten Kudus, dengan subjek para peserta didik kelas 3 semester 1 tahun pelajaran 2014/2015. Jumlah peserta didik ada 21, dengan rincian 9 laki-laki dan 12 perempuan. Adapun yang menjadi objek penelitian adalah pembelajaran membaca aksara Jawa. Proses penelitian dilaksanakan dalam dua siklus yang meliputi empat tahapan, yaitu tahap perencanaan, tahap pelaksanaan, tahap observasi, serta tahap analisis dan refleksi. Berdasarkan hasil penelitian dapat disimpulkan terdapat peningkatan kualitas pembelajaran baik proses maupun hasil membaca aksara Jawa pada peserta didik kelas 3 SD 2 Honggosoco Kecamatan Jekulo Kabupaten Kudus. Peningkatan kualitas proses pembelajaran tersebut ditandai dengan meningkatnya: 1) jumlah kualitas peserta didik yang aktif dalam kegiatan apersepsi maupun dalam kegiatan pembelajaran; 2) jumlah peserta didik yang tertarik dan termotivasi dalam kegiatan pembelajaran membaca aksara Jawa; dan 3) jumlah peserta didik yang sudah mampu membaca aksara Jawa dengan teknik yang benar dengan menggunakan metode lawaran. Adapun peningkatan kualitas hasil pembelajaran ditandai dengan meningkatnya jumlah peserta didik yang mencapai batas ketuntasan, yaitu pada siklus 1 adalah 15 peserta didik dari 22 peserta didik (71\%) yang mencapai kategori cukup dan baik. Pada siklus 2 menjadi 22 peserta didik (100\%). Sedangkan kecepatan rata-rata membaca mencapai 25.96. Adapun langkah-langkah efektif yang dilakukan oleh peneliti untuk mengoptimalkan metode ini, antara lain: 1) membagi peserta didik secara berkelompok yang didasarkan perbedaan tingkat kemampuan membaca aksara Jawa; 2) memberi kesempatan kepada peserta didik untuk berlatih membaca aksara Jawa melalui metode lawaran; 3) mengintegrasikan keterampilan membaca aksara Jawa dengan keterampilan berbahasa lainnya, seperti berbicara, menulis, dan mendengarkan; dan 4) mengaplikasikan membaca aksara Jawa dalam kegiatan seni di lingkungan sekolah khususnya sesuai pengalaman yang didapat peserta didik selama penelitian. Prinsip pokok pada metode ini adalah mengetahui, berlatih, menerapkan, memeragakan, sehingga peserta didik mengaktualisasikan membaca aksara Jawa dengan benar.

Kata Kunci: Membaca aksara Jawa, Lawaran.

\section{PENDAHULUAN}

Mata Pelajaran Bahasa Jawa merupakan mata pelajaran muatan lokal yaitu pelajaran yang mengembangkan ciri khas dan potensi daerah, termasuk keunggulan daerah. Di samping itu bahasa Jawa memiliki peran sentral dalam perkembangan budi pekerti, budaya Jawa, intelektual sosial dan emosional peserta didik, serta merupakan penunjang bahasa Indonesia.

Lebih tegas lagi apabila dilihat dari tujuan standar kompetensi dan kompetensi dasar mata pelajaran bahasa
Jawa untuk sekolah dasar/madrasah (SD/MI), sekolah menengah pertama (SMP), Madrasah Tsanawiyah (MTs), dan SMPLB diharapkan siswa memiliki kemampuan antara lain:

berkomunikasi secara efektif dan efisien sesuai dengan etika dan budaya Jawa baik secara tertulis maupun lisan (2 Menghargai dan bangga menggunakan bahasa jawa sebagai bahasa daerah yang mendukung bahasa Indonesia (3)menikmati dan memanfaatkan karya sastra untuk memperluas budi pekerti. (4) Menghargai danmembanggakan sastra Jawa sebagai khasanah budaya Jawa. 
Hingga sekarang ini, kegemaran membaca huruf Jawa pada siswa masih kurang. Masalah tersebut dapat dilihat dari kenyataan bahwa siswa malas untuk belajar membaca huruf Jawa. Mereka hanya mau belajar jika keadaan mendesak, misalnya saja akan ada ulangan atau ujian. Selain itu, kurangnya keantusiasan siswa terhadap pelajaran bahasa Jawa juga terlihat saat proses belajar mengajar. Saat memperoleh pokok bahasan dan materi yang berkaitan dengan membaca huruf Jawa, banyak siswa enggan atau mengeluh.

Upaya pembinaan telah dilakukan secara terus menerus dan berkesinambungan sejak siswa duduk di bangku Sekolah Dasar. Namun, kenyataan menunjukkan bahwa kemampuan membaca huruf Jawa siswa Sekolah Dasar/MI pada umumnya masih jauh dari yang diharapkan. Seperti kenyataannya aktifitas pembelajaran bahasa Jawa di SD 2 Honggosoco Kecamatan Jekulo Kabupaten Kudus masih jauh dari harapan. Hal ini dibuktikan dari hasil angket menunjukkan bahwa siswa Kelas 3 SD 2 Honggosoco Kecamatan Jekulo Kabupaten Kudus dalam mengikuti pelajaran Bahasa Jawa, masih menganggap pelajaran membosankan (67 $\%)$, biasa-biasa saja (13\%) dan sisanya menganggap sepele (20\%). Hasil angket lainnya menunjukkan siswa dalam mengikuti pelajaran bersikap pasif dengan perincian keaktifan bertanya dan mengemukakan pendapat sangat rendah $(88 \%)$ dan sisanya yang aktif, tidak mau bekerjasama dalam kelompok (12\%).

Berdasarkan latar belakang masalah, peneliti dapat mengidentifikasi berbagai permasalahan yang muncul dalam pembelajaran mata pelajaran bahasa Jawa materi membaca huruf Jawa pada Kelas 3 SD 2 Honggosoco Kecamatan Jekulo Kabupaten Kudus adalah : rendahnya motivasi dan minat belajar siswa mengikuti pembelajaran, metode mengajar guru kurang bervariasi, monoton hanya mengedepankan ceramah saja, peserta didik masih menganggap isi materi pelajaran terlalu rumit, dalam kegiatan pembelajaran guru kurang melibatkan secara aktif peserta didik dalam mengikuti pembelajaran, rendahnya keinginan peserta didik untuk tertarik dan antusias mengikuti pelajaran.

Berdasarkan identifikasi masalah yang ada, maka rumusan masalah dalam penelitian ini adalah: 1) bagaimanakah proses pembelajaran membaca huruf Jawa dengan menggunakan metode lawaran peserta didik kelas 3 SD 2 Honggosoco Kecamatan Jekulo Kabupaten Kudus semester 1 tahun pelajaran 2014/2015 ; 2) seberapa banyak peningkatan keterampilan dan motivasi membaca huruf Jawa dengan menggunakan metode lawaran peserta didik kelas 3 SD 2 Honggosoco Kecamatan Jekulo Kabupaten Kudus semester 1 tahun pelajaran 2014/2015; 3) bagaimanakah perubahan perilaku/motivasi peserta didik dalam pembelajaran membaca aksara Jawa dengan menggunakan metode metode lawaran peserta didik kelas 3 SD 2 Honggosoco Kecamatan Jekulo Kabupaten Kudus semester 1 tahun pelajaran 2014/2015 ?

Tujuan penelitian ini adalah untuk: 1) mendeskripsi proses pembelajaran membaca huruf Jawa dengan menggunakan metode lawaran peserta didik kelas 3 SD 2 Honggosoco Kecamatan Jekulo Kabupaten Kudus semester 1 tahun pelajaran 2014/2015, 2) mendeskripsi peningkatan keterampilan dan motivasi membaca huruf Jawa dengan menggunakan metode lawaran peserta didik kelas 3 SD 2 Honggosoco Kecamatan Jekulo Kabupaten Kudus semester 1 tahun pelajaran 2014/201 , 3) mengidentifikasi perubahan perilaku/motivasi peserta didik dalam pembelajaran membaca aksara Jawa dengan menggunakan metode metode lawaran peserta didik kelas 3 SD 2 Honggosoco Kecamatan 
Jekulo Kabupaten Kudus semester 1 tahun pelajaran 2014/2015 .

Penelitian ini diharapkan dapat dimanfaatkan sebagai panduan guru dalam pembelajaran membaca huruf Jawa di SD/sederajat dengan memanfaatkan metode lawaran, memberikan motivasi dan pengalaman baru bagi Peserta Didik untuk meningkatkan keterampilan dan motivasi membaca huruf Jawa melalui pembelajaran dengan metode lawaran, dan dapat memberikan masukan pada sekolah untuk meningkatkan hasil belajar melalui penerapan metode-metode pembelajaran yang inovatif.

\section{LANDASAN TEORITIS DAN HIPOTESIS TINDAKAN}

Pada bagian ini akan dikaji tentang strategi pembelajaran bahasa Jawa yang meliputi: Model Pembelajaran Kooperatf (Cooperatif learning) dan Model Pembelajaran Metode Tartil yang selanjutnya menjadi Metode Lawaran. Kata lawaran dalam Bau Sastra Jawa berarti wantahan atau utuh. Penelitian ini berupaya untuk meningkatkan kecepatan membaca huruf Jawa dan merupakan penelitian tindakan kelas yang terdiri dari dua siklus. Pada penelitian ini akan dikaji tentang peningkatan kecepatan membaca huruf Jawa siswa Kelas 3 SD Honggosoco 2 Jekulo Kudus. Peneliti akan menghadirkan Metode Tartil dengan berbasis model pembelajaran kooperatif saat pembelajaran, sehingga diharapkan siswa dapat berlatih membaca dengan lebih lancar dan cepat secara tarik menarik antara siswa satu dengan yang lain untuk membaca huruf Jawa secara utuh (lawaran) sehingga pembelajaran akan lebih menyenangkan.

Hodgson (dalam Tarigan 1987 :

7) berpendapat bahwa membaca adalah suatu proses yang dilakukan serta dipergunakan untuk memperoleh pesan, yang hendak disampaikan oleh penulis melalui media kata-kata atau bahasa tulis. Suatu proses yang menuntut agar kelompok kata yang merupakan suatu kesatuan akan terlihat dalam suatu pandangan sekilas, dan agar makna katakata secara individual akan dapat diketahui. Kalau hal ini tidak terpenuhi, maka pesan yang tersurat dan yang tersirat tidak akan tertangkap atau dipahami, dan proses membaca itu tidak terlaksana dengan baik.

Dari segi linguistik Anderson (dalam Tarigan 1987 : 7) berpendapat membaca adalah suatu proses penyandian kembali dan pembacaan sandi, berlainan dengan berbicara dan menulis yang justru melibatkan penyandian. Sebuah aspek pembacaan sandi adalah menghubungkan kata-kata tulis dengan makna bahasa lisan yang mencakup pengubahan tulisan menjadi bunyi yang bermakna.

Dalam Kamus Besar Bahasa Indonesia (1997 : 62) disebutkan bahwa membaca adalah melihat serta memahami isi dari apa yang tertulis (dengan melisankan atau hanya dalam hati). Dengan demikian, kegiatan membaca dapat pula diartikan sebagai suatu proses yang dilakukan serta dipergunakan oleh pembaca untuk memperoleh pesan yang hendak disampaikan oleh penulis melalui media tulis.

Crawley dan Mountain (dalam Rahim 2007 : 2) berpendapat bahwa membaca pada hakikatnya adalah suatu yang rumit yang melibatkan banyak hal, tidak hanya sekadar melafalkan tulisan, tetapi juga melibatkan aktivitas visual, berpikir, psikolinguistik, dan metakognitif. Sebagai proses visual membaca merupakan menerjemahkan simbol tulis ke dalam kata-kata lisan. Sebagai suatu proses berpikir, membaca mencakup aktivitas pengenalan kata, pemahaman literal, interpretasi, membaca kritis, dan pemahaman kreatif. Pengenalan kata bisa berupa aktivitas membaca kata-kata dengan menggunakan kamus. 
Berdasarkan beberapa pendapat yang telah dikemukakan di atas, maka dapat disimpulkan bahwa membaca adalah suatu proses yang dilakukan serta dipergunakan untuk memperoleh pesan, yang hendak disampaikan oleh penulis melalui media kata-kata atau bahasa tulis dan suatu terjemahan simbol tulis ke dalam kata-kata lisan.

\section{Pembelajaran kooperatif (Cooperative} learning)

Strategi pembelajaran koperatif merupakan strategi pembelajaran yang melibatkan siswa bekerja secara berkolaborasi untuk mencapai tujuan bersama( Eggen and Kauchak, dalam Trianto, S.Pd, M.Pd.2007 : 41). Pembelajaran kooperatif mempunyai efek yang berarti terhadap penerimaan yang luas terhadap kergaman, ras, budaya, dan agama serta sosial ( Ibrahim, dkk, 2000 : 9) hal ini memberikan peluang kepada siswa yang berbeda latar belakang dan kondisi untuk saling bergantung.

Menurut Ibrahim dkk ( 2000 : 10

) Pembelajaran kooperatif (Cooperative Learning) dilaksanakan sangat sederhana dengan menggunakan enam (6) fase kegiatan pembelajaran, yaitu: 1) Menyampaikan tujuan dan memotivasi siswa; 2) menyakan informasi yaitu guru menyajikan informasi kepada siswa lewat bacaan yang ada penerapan dari materi yang disampaikan oleh guru; 3) mengorganisasiakan siswa ke dalam kelompok kooperatif untuk membaca secara bergantian per kelompok; 4) membimbing kelompok bekerja dan belajar; 4) evaluasi; 5) pemberian penghargaan

Secara rinci skema strategi pembelajaran tim pendengar dalam kegiatan belajar mengajar dapat digambarkan dengan menggunakan metode tartil dan lawaran seperti di bawah ini.

Metode tartil sebenarnya bersumber pada cara pengajaran di pondok pesantren tempo dulu yang mengajar para santri dengan cara membaca nyaring bersama-sama kitab yang harus mereka kaji. Pada awalnya bagi yang tidak bisa membaca akan mengalami kesulitan karena tertinggal dengan teman yang lain, akan tetapi karena suasana kelompok yang mendukung untuk membaca, maka tanpa disadari terbawa dan termotivasi untuk dapat membaca.

Penggabungan antara strategi pembelajaran kooperatif dengan metode tartil

yang selanjutnya disebut metode lawaran. Metode ini mengutamakan kerja sama kelompok untuk menarik anggota yang tertinggal dengan cara membaca apa adanya secara perlahan dan bersama-sama.

Penelitian yang relevan dan mendukung teori-teori di atas adalah penelitian tindakan kelas dari Dwi Saeful Mujab (2008) dengan judul Upaya Peningkatan Kecepatan Membaca Huruf Jawa Siswa Kelas 3 SD Negeri Jenarsari Kendal dengan Menggunakan Metode Qiro'ati pada mata pelajaran Bahasa Jawa siswa kelas 3 SD Negeri Jenarsari Kendal Semester 1 Tahun pelajaran 2007/2008.

Dari penelitian tersebut diperoleh kesimpulan bahwa pembelajaran berbasis masalah mampu; 1)meningkatkan gairah belajar siswa sebesar $80 \%$; 2) meningkatkan kerja kelompok siswa sebesar $40 \%$; 3) meningkatkan prestasi belajar siswa dengan kenaikan nilai sebesar 0,4

Dari hal tersebut ada beberapa temuan yang unik dan menarik yaitu; pertama, siswa lebih senang dalam mengikuti pelajaran apabila diciptakan suasana kelompok belajar yang mendukune, kedua; siswa yang merasa kesulitan membaca akan termotivasi dengan dibantu oleh temannya, ketiga; guru dalam menyiapkan model pembelajaran harus bervariasi agar siswa tertantang dan tertarik mengikuti pelajaran. 
Hipotesis tindakan yang diajukan dalam penelitian ini adalah dengan menggunakan model pembelajaran Metode Tartil dapat meningkatkan minat, motivasi, kerjasama kelompok dan hasil belajar siswa Kelas 3 SD 2 Honggosoco Kecamatan Jekulo Kabupaten Kudus pada mata pelajaran Bahasa Jawa.

\section{METODE PENELITIAN}

Penelitian ini dilaksanakan di kelas 3 SD 2 Honggosoco Kecamatan Jekulo Kabupaten Kudus Mata pelajaran Bahasa jawa pada materi pokok membaca huruf Jawa

Subyek penelitian tindakan kelas ini adalah peserta didik kelas 3 SD 2 Honggosoco Kecamatan Jekulo Kabupaten Kudus Semester 1 Tahun Pelajaran 2014/2015 yang terdiri atas 11 peserta didik perempuan dan 10 peserta didik laki-laki, sehingga seluruhnya berjumlah 22 peserta didik. Waktu penelitian selama tiga bulan yaitu bulan Agustus, September, dan Oktober 2014

Desain yang digunakan dalam penelitian ini adalah penelitian tindakan kelas (PTK) atau Classroom Action Research. Penelitian tindakan kelas adalah suatu penelitian yang dilakukan secara sistematis reflektif terhadap berbagai tindakan yang dilakukan oleh guru, mulai dari perencanaan sampai dengan penilaian terhadap tindakan nyata di kelas yang berupa kegiatan belajar mengajar untuk memperbaiki kondisi pembelajaran yang dilakukan.

Ada beberapa model metode penelitian tindakan kelas. Salah satu model penelitian tindakan kelas yang peneliti pilih adalah model dari Stepen Kemmis dan Robbin Mc Taggart.

Model tersebut menyebutkan bahwa penelitian tindakan kelas menggunakan beberapa siklus. Setiap siklus terdiri dari empat langkah, yaitu perencanaan (Planning), tindakan (acting ), observasi (observing), refleksi (reflecting)
Sesudah sesuatu siklus selesai diimplementasikan, khususnya sesudah adanya refleksi, kemudian diikuti dengan adanya perencanaan ulang (replanning) tau revisi terhadap implementasi siklus sebelumnya. Selanjutnya, berdasrkan perencanaan ulang tersebut dilaksanakan dalam bentuk siklus tersendiri. Demikian untuk seterusnya, satu siklus diikuti dengan siklus berikutnya. (Basuki Wibowo.2005: hal 16-18)

Pada penelitian tindakan kelas ini peneliti menggunakan 2 siklus yang berkelanjutan yaitu proses tindakan pada siklus I dan siklus II. Penelitian ini bertujuan untuk memperbaiki pelaksanaan pembelajaran. Siklus ini terdiri dari empat komponen, yaitu perencanaan, tindakan, pengamatan atau observasi, dan refleksi. Keempat komponen tersebut dipandang sebagai siklus. Jika tindakan pada siklus I nilai rata-ratanya belum mencapai target yang telah ditentukan, akan diperbaiki pada siklus II. Keempat komponen tersebut yaitu : perencanaan, tindakan observasi, refleksi.

Variabel dalam penelitian ini ada 2, yaitu : variable input dan variable output. Variabel input-output pada penelitian ini adalah keterampilan membaca huruf Jawa. Tindakan yang akan dilakukan pada pembelajaran membaca huruf Jawa yaitu guru membagikan wacana menggunakan huruf Jawa pada peserta didik. Setelah itu guru memberikan soal apersep[si pada peserta didik, dan guru mencatat peserta didik yang mengalami kesulitan dalam membaca huruf Jawa. Target yang diharapkan adalah dengan metode Lawaran, keterampilan membaca huruf Jawa peserta didik dapat bertambah.

Variabel proses adalah pembelajaran kecepatan membaca wacana menggunakan huruf Jawa dengan metode lawaran. Dalam yang menekankan peserta didik latihan secara aktif, namun bersifat sederhana, sehingga 
diharapkan mampu meningkatkan keterampilan membaca huruf Jawa.

Instrumen penelitian yang digunakan untuk mengumpulkan data dalam penelitian ini berupa tes dan non tes. Tes yang digunakan untuk mengumpulkan data tentang kesulitan membaca huruf Jawa berupa tes membaca huruf Jawa.

Penelitian diawali dengan pelaksanaan tes awal atau pretes untuk mengetahui pengetahuan dan kemampuan peserta didik membaca wacana menggunakan huruf Jawa. Setelah proses pembelajaran, diadakan tes membaca kaliamt menggunakan huruf Jawa. Tes ini dilaksanakan untuk mengetahui kecepatan peserta didik membaca huruf Jawa setelah mengikuti proses pembelajaran.

Tes yang digunakan untuk mengukur keterampilan membaca huruf Jawa peserta didik berupa kalimat menggunakan huruf Jawa yang telah disiapkan oleh peneliti. Tingkat kesulitan dijadiakan pedoman untuk memperbaiki strategi pembelajaran berikutnya.

Teknik dan alat pengumpulan data dalam penelitian tindakan kelas ini meliputi: observasi, wawancara, angket, tes dan studi dokumentasi.

Dalam penelitian tindakan kelas ini, observasi yang digunakan adalah observasi partisipan dengan derajat keterlibatan pemeran serta sebagai pengamat, artinya pengamat tidak sepenuhnya sebagai pemeran serta tetapi masih melakukan fungsi pengamatan atau pengamat pura-pura menjadi anggota kelompok yang diamati.

Hal tersebut dilakukan dengan pertimbangan : (1) agar proses pengamatan tidak mengganggu kegiatan orang yang diamati; (2) peristiwa yang diamati dapat berjalan wajar; dan (3) keterbatasan waktu dan tenaga. Metode observasi ini menggunakan penginderaaan langsung terhadap suatu benda, kondisi, situasi atau perilaku. Observasi dilakukan untuk memperoleh informasi mengenai tingkat minat peserta didik dalam kelompok selama mengikuti kegiatan pembelajaran.

Wawancara adalah proses memperoleh keterangan untuk tujuan penelitian dengan cara tanya jawab, baik secara langsung maupun tidak langsung dengan sumber data (Soeharto 1993:114).

Wawancara ini dilakukan untuk mengetahui kesiapan awal dan motivasi peserta didik dalam mengikuti kegiatan pembelajaran.

Angket merupakan proses memperoleh keterangan untuk tujuan penelitian dengan cara memberikan daftar pertanyaan yang telah dipersiapkan. Daftar angket ini digunakan untuk memperoleh informasi mengenai minat peserta didik dalam membaca huruf Jawa

Tes adalah proses untuk meperoleh informasi dengan cara memberikan soal tes praktek yang harus dilakuakan oleh peserta didik.

Tes ini digunakan untuk memperoleh keterangan mengenai peningkatan kemampuan membaca huruf Jawa

Studi dokumentasi sebagai pelengkap data, dan dokumen-dokumen tersebut diharapkan dapat menjadi nara sumber yang dapat menjawab pertanyaan-pertanyaan yang tidak memungkinkan melalui wawancara, observasi, angket ataupun tes.

Agar data valid dan reliabel, selama pengumpulan data dilakukan validasi data. Selama proses pengumpulan data perlu dilaksanakan dua jenis validasi data. Adapun jenisnya adalah sebagai berikut;

Agar dalam memaknai kebenaran terhadap informasi yang diperoleh menunjukkan ketepatan atau representasi fenomena yang dikaji, maka peneliti melakukan validasi. Dalam penelitian ini kegiatan validasi dilakukan dengan triangulasi yaitu melakukan komparsi pada jenis informasi yang berbeda dan 
menggunakan metode yang berbeda (observasi, wawancara, angket, dan dokumentasi).

Untuk mengetahui tingkat validasi tes prestasi belajar Bahasa Jawa materi membaca huruf Jawa dalam penelitian tindakan kelas ini, instrumen tes akan diuji dengan menggunakan uji praktek dengan menggunakan pksoran nilai yang telah dipersiapkan.

Dalam penelitian tindakan kelas ini, analisis data meliputi tiga langkah pokok, yaitu: (1) reduksi data; (2) penyajian data; dan (3) penarikan kesimpulan dan verifikasi.

Reduksi data, penyajian data, dan penarikan kesimpulan sebagai sesuatu yang jalin menjalin pada saat sebelum, selama dan sesudah pengumpulan data dalam bentuk yang sejajar untuk membangun wawasan umum yang disebut analisis.

\section{HASIL PENELITIAN DAN PEMBAHASANNYA}

Penelitian ini dilaksanakan dengan tiga kali tindakan siklus, yaitu prasiklus, siklus I dan siklus II. Sebelum dimulai tindakan siklus 1, diadakan apersepsi mata pelajaran bahasa Jawa pokok bahasan membaca huruf Jawa. Hasil pembelajaran pada prasiklus yang berupa data tes dikelompokkan dalam distribusi frekuensi sebgai berikut :

Tabel 1 Hasil Kecepatan Membaca Huruf Jawa Prasiklus

\begin{tabular}{|c|c|c|c|}
\hline No & Kategori & $\begin{array}{c}\text { Jumlah } \\
\text { Kata/Menit }\end{array}$ & f \\
\hline 1. & Sangat baik & $31-35$ & - \\
2. & Baik & $26-30$ & - \\
3. & Cukup & $21-25$ & 3 \\
4. & Kurang & $16-20$ & 14 \\
5. & Sangat & $0-15$ & 4 \\
& Kurang & & \\
\hline & Jumlah & & 21 \\
\hline
\end{tabular}

Hasil tes prasiklus, peserta didik yang memperoleh jumlah kata untuk kategori sangat baik yaitu rentang jumlah kata 31 - 35 tidak dicapai oleh peserta didik. Kategori baik yaitu dengan rentang jumlah kata 26-30 dicapai oleh satu peserta didik. Kategori cukup dengan rentang jumlah kata 21-25 dicapai oleh 3 peserta didik. Kategori kurang dengan rentang jumlah kata 16-20 dicapai 14 peserta didik. Sedangkan untuk kategori sangat kurang dengan rentang jumlah kata 0-15 dicapai 4 peserta didik. Jadi rata-rata kecepatan membaca huruf Jawa Kelas 3 SD 2 Honggosoco Kecamatan Jekulo Kabupaten Kudus yang pembelajarannya menggunakan materi metode Lawaran sebesar 17.42 dengan kategori kurang. Dengan demikian secara keseluruhan kecepatan membaca huruf Jawa peserta didik belum memenuhi target 25 jumlah kata dalam rata-rata kelas. Adapun jumlah kata dalam ratarata kelas 17.42 tersebut berasal dari jumlah kata yang diperoleh oleh peserta didik dalam kecepatan membaca huruf Jawa.

Dari hasil observasi diketahui bahwa pada kegiatan pembelajaran prasiklus. Kondisi peserta didik selama mengikuti kegiatan pembelajaran kurang aktif dan tidak antusias, sehingga hasil yang diperoleh belum mencapai batas jumlah kata yang ditentukan. Hal tersebut disebabkan materi yang disampaikan oleh guru kurang menarik peserta didik.

Setelah dilakukan refleksi kegiatan pembelajaran prasiklus, maka perlu dicarikan solusi atau materi yang menarik peserta didik lebih aktif dan kreatif dalam pembelajaran membaca huruf Jawa. Maka perlu dilakukan tindakan pembelajaran untuk meningkatkan kecepatan membaca huruf Jawa peserta didik.

Berdasarkan wawancara yang diajukan pada peserta didik yang memperoleh jumlah kata yang terbanyak dan yang memperoleh paling sedikit, diketahui bahwa pembelajaran membaca huruf Jawa merupakan kegiatan yang sulit dan kurang menyenangkan bagi peserta didik, alasannya peserta didik 
kurang memahami huruf Jawa selain itu belum tahu cara memahami huruf Jawa dengan mudah.

Alasan yang lain yaitu teks yang terlalu banyak sehingga peserta didik merasa jenuh dan bosan dalam membaca huruf Jawa. Peserta didik menginginkan teks yang jadikan bacaan tidak terlalu panjang. Berdasarkan hasil tersebut dijadikan sebagai pertimbangan untuk memberikan tindakan pada kegiatan pembelajaran siklus berikutnya.

Data non tes yang lain dalam penelitian ini berupa jurnal peserta didik, tujuannya yaitu untuk menggali keinginan peserta didik dalam mengikuti kegiatan pembelajaran membaca huruf Jawa. Dari jurnal tersebut diketahui bahwa kegiatan pembelajaran membaca huruf Jawa merupakan materi yang kurang menyenangkan karena peserta didik kurang mengerti dan kurang memahaminya. Peserta didik mengungkapkan pembelajaran membaca huruf jawa kurang menyenangkan karena guru dalam menyampaikan pelajaran hanya monoton.

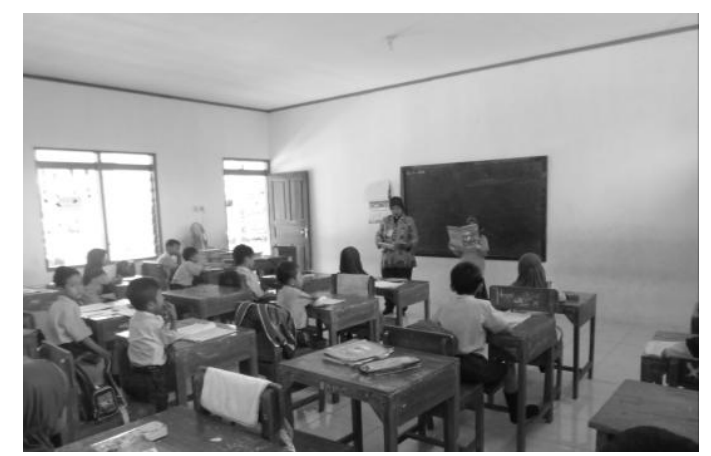

Gambar 1. Suasana pembelajaran monoton

Berdasarkan jurnal tersebut diketahui bahwa peserta didik mengalami kesulitan untuk pembelajaran membaca huruf Jawa. Selain itu, guru dalam menyampaikan materi hanya secara garis besarnya saja dan kurang dipahami oleh peserta didik, sehingga jumlah kata yang dikuasai peserta didik kurang maksimal sesuai dengan apa dengan yang ditargetkan.
Hasil tes pada tindakan pembelajaran siklus I secara lengkap (terlampir) dan secara ringkas disajikan dalam bentuk tabel berikut

Tabel 2 Hasil Kecepatan Membaca Huruf Jawa Siklus I

\begin{tabular}{|c|c|c|c|}
\hline No & Kategori & $\begin{array}{c}\text { Jumlah } \\
\text { Kata/Kata }\end{array}$ & Frekuensi \\
\hline 1. & Sangat & $31-35$ & - \\
2. & baik & $26-30$ & 5 \\
3. & Baik & $21-25$ & 10 \\
4. & Cukup & $16-20$ & 6 \\
5. & Kurang & $0-15$ & - \\
& Sangat & & \\
& kurang & & 21 \\
\hline & Jumlah & & \multicolumn{2}{|l}{} \\
\hline
\end{tabular}

Hasil tes siklus I, peserta didik yang memperoleh jumlah kata untuk kategori sangat baik yaitu rentang jumlah kata 31 - 35 tidak dicapai oleh peserta didik. Kategori baik yaitu dengan rentang 26-30 dicapai oleh 5 peserta didik. Kategori cukup dengan rentang jumlah kata 21-25 dicapai oleh 10 peserta didik. Kategori kurang dengan rentang jumlah kata 16-20 dicapai 6 peserta didik. Sedangkan untuk kategori sangat kurang dengan rentang nilai 0-15 tidak dicapai oleh peserta didik. Jadi rata-rata jumlah kata dalam kecepatan membaca huruf Jawa Kelas 3 SD 2 Honggosoco Kecamatan Jekulo Kabupaten Kudus yang pembelajarannya menggunakan materi model Lawaran sebesar 23.80 dengan kategori cukup. Dengan demikian secara keseluruhan kecepatan membaca huruf Jawa peserta didik belum memenuhi target 25 jumlah kata dalam rata-rata kelas. Adapun rata-rata jumlah kata 22.54 tersebut berasal dari jumlah kata dalam kecepatan membaca huruf Jawa. 


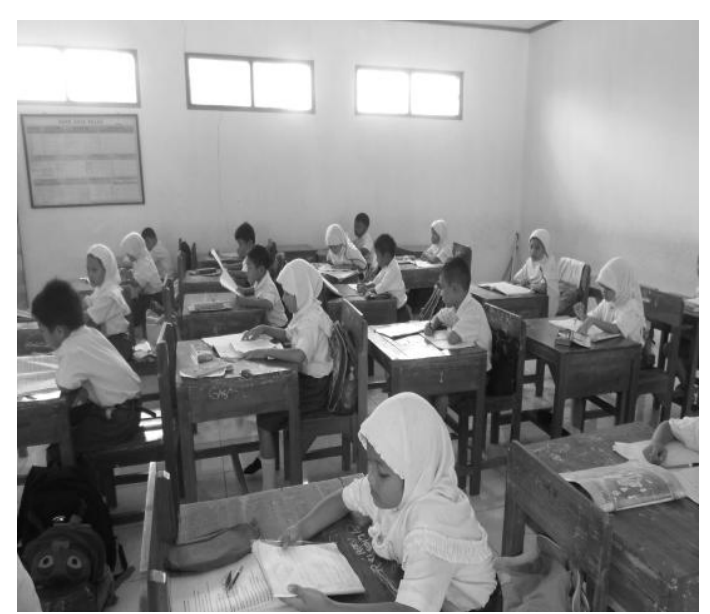

Gambar 2. Membaca huruf Jawa pada siklus I

Data yang diperoleh dari hasil kegiatan observasi dalam kegiatan pembelajaran membaca huruf Jawa siklus I memberikan informasi penting bagi guru. Hal ini guru memberikan apersepsi singkat dan tujuan pembelajaran peserta didik memusatkan perhatiannya terhadap penjelasan yang diberikan oleh guru.

Dari observasi yang dilakukan pada siklus I ini tanggapan awal peserta didik pada saat guru hadir dan mulai memperkenalkan materi pembelajaran membaca huruf Jawa sudah baik. Perhatian peserta didik pada materi yang disampaikan kurang, keaktifan peserta didik selama pembelajaran berlangsung kurang antusias dan pada saat kegiatan evaluasi belajar peserta didik kurang menguasai materi membaca huruf Jawa, sehingga jumlah kata yang dikuasai sedikit.

Kegiatan wawancara ditujukan pada peserta didik yang memperoleh nilai tinggi dan peserta didik yang memperoleh nilai rendah. Hasil dari kegiatan wawancara ini dapat dijadikan sebagai bahan refleksi untuk kegiatan pembelajaran pada siklus berikutnya.

Ada beberapa peserta didik yang menganggap bahwa tugas yang diberikan itu tidak penting, sehingga peserta didik kurang berusaha dalam mengerjakannya. Namun demikian ditemukan beberapa peserta didik yang menganggap serius, yaitu terbukti adanya peserta didik yang bersungguh-sungguh dalam mengerjakan sehingga dapat menyelesaikan tugas dengan baik

Data yang diperoleh dari jurnal yang dibagikan pada peserta didik memberikan informasi penting bagi guru. Dengan jurnal tersebut guru mengetahui bagaimana tanggapan peserta didik terhadap pembelajaran yang telah dilakukan.

Data yang diperoleh menunjukkan bahwa peserta didik senang pada kegiatan pembelajaran membaca huruf Jawa dengan materi model Lawaran. Peserta didik lebih mudah membaca dan memahami teks bacaan yang memakai huruf Jawa, walaupun masih ada hambatan karena peserta didik kurang memperhatikan pembelajaran dengan serius.

Hasil tes pada tindakan pembelajaran siklus II secara lengkap (terlampir) dan secara ringkas disajikan dalam bentuk tabel berikut:

\section{Tabel 3 Hasil Kecepatan} Membaca Huruf Jawa Siklus II

\begin{tabular}{|c|c|c|c|}
\hline $\begin{array}{c}\text { N } \\
\text { o }\end{array}$ & Kategori & $\begin{array}{c}\text { Jumlah } \\
\text { Kata/Menit }\end{array}$ & $\mathbf{f}$ \\
\hline 1. & Sangat & $31-35$ & 6 \\
2. & baik & $26-30$ & 5 \\
3. & Baik & $21-25$ & 10 \\
4. & Cukup & $16-20$ & - \\
5. & Kurang & $0-15$ & - \\
& Sangat & & \\
& Kurang & & \\
\hline & Jumlah & & 21 \\
\hline
\end{tabular}

Hasil tes siklus II, peserta didik yang memperoleh jumlah kata untuk kategori sangat baik yaitu rentang jumlah kata 31-35 dicapai oleh 6 peserta didik. Kategori baik yaitu dengan rentang jumlah kata 26-30 dicapai oleh 5 peserta didik. Kategori cukup dengan rentang jumlah kata 21-25 dicapai oleh 10 peserta didik. Kategori kurang dengan rentang jumlah kata 16-20 tidak dicapai oleh peserta didik. Sedangkan untuk 
kategori sangat kurang dengan rentang jumlah kata 0-15 tidak dicapai oleh peserta didik. Jadi rata-rata kecepatan membaca huruf Jawa Kelas 3 SD 2 Honggosoco Kecamatan Jekulo Kabupaten Kudus yang pembelajarannya menggunakan materi model Lawaran sebesar 23.80 dengan kategori baik. Dengan demikian secara keseluruhan kecepatan membaca huruf Jawa peserta didik memenuhi target jumlah kata yang diperoleh 25 dalam rata-rata kelas. Adapun rata-rata jumlah kata 25.96 tersebut berasal dari jumlah kata dalam kecepatan membaca huruf Jawa.

Hasil tes membaca huruf Jawa dengan materi model Lawaran pada siklus II di atas didukung dengan hasil pengamatan terhadap peserta didik pada waktu proses belajar mengajar. Pada waktu kegiatan pembelajaran berlangsung sebagian besar peserta didik memiliki antusias yang tinggi. Ada sebagian kecil peserta didik yang terlihat pasif namun ketidakaktifan peserta didik tersebut disebabkan oleh situasi dan kondisi peserta didik itu sendiri. Dalam siklus II menunjukkan semua peserta didik sudah bersikap baik karena tidak memiliki keraguan dalam mengerjakan tes membaca huruf Jawa. Ketika diadakan tes membaca huruf Jawa dengan materi model Lawaran, mereka langsung mengerjakan tugas dengan baik, walaupun masih ada peserta didik yang berbicara tidak relevan, mencari perhatian, tetapi akhirnya mengerjakan tugas dengan baik.

$\begin{array}{ccr}\text { Data } & \text { hasil } & \text { wawancara } \\ \text { menunjukkan } & \text { bahwa } & \text { kegiatan }\end{array}$ pembelajaran membaca huruf Jawa dengan materi model Lawaran tersebut ternyata bisa menarik perhatian peserta didik. Dengan materi tersebut peserta didik lebih aktif dan lebih bisa memahami bacaan huruf Jawa, serta juga lebih mudah memahami teks berhuruf Jawa. Selain itu, peserta didik tertarik dan merasa senang belajar membaca huruf Jawa dengan menggunakan materi model Lawaran karena dengan mudah memahami teks bacaan yang memakai huruf Jawa. Dari beberapa peserta didik yang penulis wawancarai mengatakan bahwa membaca huruf Jawa dengan menggunakan materi model Lawaran lebih mudah dipahami daripada menggunakan model materi yang lain.

Setelah kegiatan belajar mengajar, kegiatan selanjutnya dalam penelitian ini adalah membagikan lembar jurnal pada peserta didik tujuannya yaitu untuk mengetahui tanggapan peserta didik terhadap kegiatan pembelajaran yang sudah dilakukan. Data jurnal menunjukkan bahwa kegiatan pembelajaran membaca huruf Jawa dengan materi model Lawaran peserta didik-peserta didik tersebut tertarik dan senang. Guru menjelaskan pembelajaran membaca huruf Jawa dengan baik sehingga peserta didik lebih mudah untuk memahami dan menguasai tentang membaca huruf Jawa.

Berdasarkan teori kecepatan membaca yang ada, standar kecepatan membaca peserta didik Sekolah Dasar berkisar 200 kata per menit. Pada penelitian ini hasil yang dicapai tidak mencapai standar kecepatan membaca pada umumnya, hasil dari penelitian dapat dilihat pada tabel di bawah ini :

Tabel 4 Perbandingan

Kecepatan Membaca Huruf Jawa

\begin{tabular}{|c|c|c|c|c|c|}
\hline \multirow[b]{2}{*}{$\begin{array}{l}\mathbf{N} \\
\mathbf{0}\end{array}$} & \multirow[b]{2}{*}{$\begin{array}{c}\text { Katego } \\
\text { ri }\end{array}$} & \multirow{2}{*}{$\begin{array}{c}\text { Jumlah } \\
\text { Kata/M } \\
\text { enit }\end{array}$} & \multicolumn{3}{|c|}{ Frekuensi } \\
\hline & & & Pra & S I & $\begin{array}{l}\text { S } \\
\text { II }\end{array}$ \\
\hline 1. & Sangat & $31-35$ & - & - & 6 \\
\hline 2. & baik & $26-30$ & - & 5 & 5 \\
\hline 3. & Baik & $21-25$ & 3 & 10 & 10 \\
\hline 4. & Cukup & $16-20$ & 14 & 6 & - \\
\hline 5. & $\begin{array}{l}\text { Kurang } \\
\text { Sangat } \\
\text { Kurang }\end{array}$ & $0-15$ & 4 & - & - \\
\hline & Jumlah & & 21 & 21 & 21 \\
\hline
\end{tabular}

Berdasarkan data pada tabel di atas dapat dibandingkan kecepatan membaca huruf Jawa dari prasiklus, 
siklus I, dan siklus II Pada prasiklus dapat dilihat bahwa penguasaan membaca huruf Jawa masih sangat jauh dari apa yang diharapkan, hal itu terlihat baru 3 peserta didik yang bisa membaca itupun kategori cukup, sedangkan peserta didik-peserta didik yang lain masih kurang menguasai membaca huruf Jawa bahkan ada yang masih sangat kurang. Dari penguasaan peserta didik membaca huruf Jawa yang masih kurang tersebut dapat diketahui bahwa materi yang digunakan kurang disukai oleh peserta didik

Pada siklus I mulai ada peningkatan yang signifikan dibandingkan pada prasiklus, pada siklus I ini sebagian besar peserta didik mulai menguasai membaca huruf Jawa. Meskipun ada peningkatan akan tetapi hasil yang dicapai belum maksimal, hal ini disebabkan masih ada sedikit hambatan yang ditemui pada saat proses belajar mengajar, pada saat guru mengajar peserta didik sudah mau memperhatikan apa yang disampaikan guru, akan tetapi peserta didik kurang aktif dalam mengikuti pembelajaran sehingga penguasaan membaca huruf Jawa belum dapat dicapai dengan maksimal.

Pada siklus II ini mengalami peningkatan yang tinggi karena hasil tersebut pada siklus I belum didapat dicapai. Hal ini membuktikan bahwa terjadi perbaikan sikap kearah yang lebih baik. Peserta didik-peserta didik tersebut rata-rata dapat mengerjakan soal tes membaca permulaan dengan baik. Mereka penuh antusias dan sungguhsungguh dalam mengerjakan tes. Selain itu mereka aktif dalam pembelajaran membaca huruf Jawa dengan materi model Lawaran.

Berdasarkan analisis hasil tes kecepatan membaca peserta didik pada siklus II mengalami peningkatan yang baik. Ini disebabkan oleh dua faktor yang mempengaruhi yaitu faktor internal dan faktor eksternal. Faktor internal meliputi pengetahuan peserta didik, sikap, motivasi, kondisi peserta didik dan minat. Adapun faktor eksternal mencakup gangguan tempat peserta didik belajar dan suasana kelas yang terkendali.

Pada proses pembelajaran siklus II telah ada peningkatan batas tuntas belajar, yakni ada 17 peserta didik yang memperoleh jumlah kata di atas batas ketuntasan yaitu 25 kata. Ini berarti batas tuntas telah terpenuhi karena jumlah peserta didik yang memperoleh di atas 25. Dengan kata lain pembelajaran peningkatan kecepatan membaca huruf Jawa dengan materi model Lawaran pada peserta didik Kelas 3 SD 2 Honggosoco Kecamatan Jekulo Kabupaten Kudus semester 1 tahun pelajaran 2014/2015 telah memenuhi hipotesis yang diajukan. Hasil tersebut diketahui telah diadakan analisis hasil tes kecepatan membaca huruf Jawa pada siklus I dan siklus II.

Perubahan perilaku belajar peserta didik pada pembelajaran membaca huruf Jawa menunjukkan bahwa perilaku belajar peserta didik setiap siklus mengalami perubahan yang lebih baik dan mengarah pada perilaku yang positif. Pada pembelajaran membaca huruf Jawa banyak memberikan pengalaman belajar yang baru bagi peserta didik sehingga wawasan dan pengetahuan mereka bisa bertambah.

\section{PENUTUP}

Hasil penelitian ini bahwa tindakan penerapan metode Lawaran menunjukkan efetifitasnya yang nyata yaitu dapat diandalkan sebagai materi pembelajaran yang baik untuk meningkatkan keterampilan membaca huruf Jawa pada siswa Kelas 3 SD 2 Honggosoco Kecamatan Jekulo Kabupaten Kudus. Meskipun belum ada standar rumus atau teori kecepatan membaca huruf Jawa dapat dilihat hasil prasikus, siklus I, dan siklus II dalam peneliltian ini mengalami peningkatan 
Setelah mengetahui pembelajaran dengan menggunakan Metode Lawaran dapat meningkatkan kecepatan membaca huruf Jawa, maka peneliti menyarankan pada guru, siswa, dan peneliti lainnya sebagai berikut : 1) guru dalam mengajarkan mata pelajaran bahasa Jawa hendaknya, menguasai berbagai pendekatan, materi, teknik pembelajaran; 2) guru yang dalam menyampaikan materi membaca huruf Jawa menggunakan metode Lawaran, hendaknya mengaitkan materi dengan lainnya, sehingga peserta didik akan terbiasa membaca huruf Jawa membaca huruf Jawa; 3) guru hendanya menciptakan suasana belajar yang tidak membosankan dan menjenuhkan bagi peserta didik; 4) perlunya penelitian lain tentang keterampilan membaca huruf Jawa untuk memperbaiki proses pembelajaran bahasa Jawa.

\section{DAFTAR PUSTAKA}

Depdiknas. 2005. Kurikulum 2006 Kurikulum Tingkat Satuan Pendidikan (KTSP) Mata Pelajaran Bahasa Jawa Sekolah Dasar. Semarang:Depdiknas.

Tim Penyusun Kamus Depdikbud. 1997. Kamus Besar Bahasa Indonesia Edisi Kedua. Jakarta : Depdikbud dan Balai Pustaka.

Haryadi. 2006. Retorika Membaca Model Metode dan Teknik. Semarang : Rumah Indonesia.

Tarigan, Henry Guntur. 1994. Membaca Sebagai Suatu Keterampilan Berbahasa. Bandung : Angkasa.

Nurhadi. 2004. Bagaimana Meningkatkan Kemampuan Membaca Edisi Kedua. Bandung : Sinar Baru Algensindo.
Nurhadi. 2005. Membaca Cepat dan Efektif. Bandung : Sinar Baru Algensindo.

Soedarso. 2002. Speed Reading Sistem Membaca Cepat dan Efektif. Jakarta : Gramedia. 